\title{
Generalized Growth
}

National Cancer Institute

\section{Source}

National Cancer Institute. Generalized Growth. NCI Thesaurus. Code C18825.

Processes that promote either specific or nonspecific formation of additional tissue mass, typically by cell proliferation. 